\title{
Is sewage sludge a valuable fertilizer? A soil microbiome and resistome study under field conditions
}

\author{
Anna Markowicz ${ }^{1}$ (1) $\cdot$ Kinga Bondarczuk $^{2} \cdot$ Aleksandra Wiekiera $^{1} \cdot$ Sławomir Sułowicz ${ }^{1}$
}

Received: 27 March 2021 / Accepted: 20 May 2021 / Published online: 7 June 2021

(c) The Author(s) 2021

\begin{abstract}
Purpose Sewage sludge land application is strongly recommended to improve soil quality and fertility despite the presence of pollutants, pathogens and antibiotic resistance genes. This study aimed to assess the fertilization value of low and recommended by law sewage sludge dose $\left(15 \mathrm{tha}^{-1}\right)$.

Materials and methods In a 540-day field study, the effect of sewage sludge on the soil physicochemical and microbial parameters, emphasising antibiotic and metal resistance spread, was investigated.

Results In contrast to expectations, sewage sludge did not improve the organic matter, nutrient content and microbial activity in the soil; therefore, the fertilization effect was not achieved. Moreover, an increase in the bioavailable $\mathrm{Cd}, \mathrm{Ni}$ and $\mathrm{Cu}$ content was observed. Canonical correspondence analysis revealed that these increases mainly explain the changes in the soil microbial community. Sixteen resistance genes and four integron classes were detected in both the total DNA and on plasmids isolated from sewage sludge. Obtained plasmids confer $\beta$-lactam resistance or extreme resistance to tetracycline $\left(>256 \mu \mathrm{g} \mathrm{mL}^{-1}\right)$. Two antibiotic resistance genes $\left(\right.$ bla $_{N P S-2}$, tet $\left.A\right)$ were transferred into the fertilized soil and detected up to 6 months after the fertilization.

Conclusion Our results provide evidence that the regulated dose of sewage sludge, even when characterized by low total metal content, may affect soil microbial microbiome and resistome. Therefore, these findings provide critical data that have public health implications, which may raise concerns about the suitability of applying sewage sludge to the soil even at the low regulated dose.
\end{abstract}

Keywords Sewage sludge $\cdot$ Soil fertilization $\cdot$ Microbial community $\cdot$ Antibiotic resistance gene $\cdot$ Metal resistance gene . Plasmid

\section{Introduction}

Over the past several decades, sewage sludge land application was strongly recommended to improve soil quality and

Responsible editor: Jizheng He

Anna Markowicz

anna.markowicz@us.edu.pl

Kinga Bondarczuk

kinga.bondarczuk@umb.edu.pl

Aleksandra Wiekiera

aleksandrawiekiera98@gmail.com

Sławomir Sułowicz

slawomir.sulowicz@us.edu.pl

1 Institute of Biology, Biotechnology and Environmental Protection, Faculty of Natural Sciences, University of Silesia, Jagiellońska 28, 40-032 Katowice, Poland

2 Centre for Bioinformatics and Data Analysis, Medical University of Białystok, Białystok, Poland productivity, reduce the need for chemical fertilizers and solve waste disposal problems (European Commission 2014; Mininni et al. 2015). Sewage sludge is a source of organic matter and several nutrients for plants, especially nitrogen, phosphorus, calcium, magnesium and potassium (Seleiman et al. 2013). Despite substantial nutrient content in sewage sludge, its land application can only partially replace industrial fertilizers. Therefore, some authors argued that the virtual value of sewage sludge as a fertilizer is low and overestimated (Kirchmann et al. 2017; de Melo et al. 2018). To ensure a reasonable amount of plant essential mineral elements and organic matter in the fertilized soil, unrealistic high amounts and annually repeated sewage sludge application is a common practice (Hamdi et al. 2019; Urra et al. 
2019). Such an approach raises environmental and public health concerns regarding the adverse effects of metals and other priority and emerging pollutants such as pharmaceuticals that are often present in the sewage sludge. All these contaminants may enter soil when sewage sludge is applied as a fertilizer (Cucina et al. 2019; da Silva Souza et al. 2020). Therefore, the policy in many countries regulated the doses of sewage sludge which may be added to the soil to obtain the fertilization effect (Mininni et al. 2015).

A matter of utmost importance is the presence of antibiotic resistant bacteria (ARB) and antibiotic resistance genes (ARGs) in sewage sludge, and its contribution to the antibiotic resistance spread (Bondarczuk et al. 2016; Chen et al. 2016; Che et al. 2019). Resistance genes are found on bacterial chromosomes and mobile genetic elements (MGEs) such as plasmids, transposons or integrons. The microbial communities from wastewater treatment plants (WWTPs) contain an immense variety of MGEs, among which resistance and multi-resistance plasmids occur ( $\mathrm{Li}$ et al. 2015; Partridge et al. 2018). Despite our understanding of the prevalence and distribution of ARGs in WWTPs, their genetic location and possible hosts, as well as their fate after they reach the environment, remain largely unknown. Moreover, knowledge about which factors affect the proliferation and distribution of ARGs in the environment, e.g., soil, is still lacking. Many studies suggest a correlation between ARGs and metal resistance genes (MRGs). There are growing evidence that disinfectant resistance genes may also be present on the same genetic element as the ARGs (Pal et al. 2015; Hu et al. 2017; Partridge et al. 2018).

Considering the current clinical significance of antibiotic resistance dissemination and the ecosystem role of the soil environment into which both selective agents and resistant bacteria are transferred, it is crucial to examine the antibiotic and metal resistance and the mobile resistome in sewage sludge and the fertilized soil. Therefore, one of the aims of this study was to characterize the soil and sewage sludge resistome. We evaluated the occurrence of class 1,2 and 3 integron integrase genes, genes conferring resistance to $\beta$-lactams, tetracycline and metals. Moreover, from the sewage sludge, plasmids conferring antibiotic resistance were isolated and characterized. Next, a field study was conducted to investigate the fertilization effects of a regulated dose of sewage sludge. During the field experiment, the physicochemical parameters $(\mathrm{pH}$, conductivity, organic matter content, heavy metal content), enzymatic activity (hydrolytic, urease, phosphatases, nitrification potential), microbial community (total cultivable bacteria, ARB, metal resistance bacteria, functional diversity), total bacterial population based on the 16S rRNA gene number and the presence of several ARGs, MRGs and integrons were monitored for eighteen months. We hypothesize that (1) the regulated dose of sewage sludge will improve the organic matter and nutrient
$(\mathrm{N}, \mathrm{P}, \mathrm{C})$ content in the soil and the activity of indigenous microbial communities; (2) the occurrence of antibiotic- and metal-resistant strains, resistance genes and mobile genetic elements will be documented in sewage sludge; and (3) horizontal gene transfer between bacteria residing in sewage sludge and indigenous soil microflora will occur.

\section{Materials and methods}

\subsection{Experimental design}

A field experiment was carried out on a green area with no history of sewage sludge application. The area was located near agricultural fields in the Silesian Upland, southern Poland $\left(50^{\circ} 32 \mathrm{~N}, 19^{\circ} 32 \mathrm{E}\right)$. The soil was sandy loam in texture with a neutral $\mathrm{pH}$. The experiment was designed as a randomized complete block $(\mathrm{RCB})$ repeated in time. The experimental field was divided into five blocks (independent replications). Each plot was approximately $15 \times 15 \mathrm{~m}$, which is a reasonable area for agricultural management. Plots were fertilized (FS) with stabilized dewatered sewage sludge at a loading rate of $15 \mathrm{t}$ dry matter ha ${ }^{-1}$. This is the maximum allowable dose according to Polish law (Polish Journal of Laws 2015). The residual sewage sludge was obtained as was described earlier (Markowicz et al. 2021). The sewage sludge was incorporated into $20 \mathrm{~cm}$ of the topsoil using a rotavator. The same agricultural management was used on the control plots without fertilization (CS). Composite soil samples were collected on day 1 (FS1, CS1) and then on days 30 (FS30, CS30), 180 (FS180, CS180), 360 (FS360, CS360) and 540 (FS540, CS540) after the treatment. Each independent soil sample was composed of five subsamples (approximately $200 \mathrm{~g}$ ) that were collected at a depth of 15-20 cm from the four corners and the centre of a square $(1 \times 1 \mathrm{~m})$ located in the middle of each plot (Margesin and Schinner 2005). The soil subsamples were then mixed, homogenized and sieved through a 2-mm mesh and used for all analyses. Sewage sludge samples were used for bacteria enumeration and physicochemical and molecular analyses.

\subsection{Physicochemical parameters of the soil and sewage sludge}

The soil and sewage sludge $\mathrm{pH}$, conductivity and moisture were assessed using ISO standards. The organic matter (OM) content in the soil and sewage sludge was assessed using the loss on ignition method (Margesin and Schinner 2005). The content of available phosphorus $(\mathrm{P})$ and total nitrogen $(\mathrm{N})$ in the sewage sludge was determined using the EgnerRiehm double lactate extraction and the Kjeldahl method, respectively. The total metal $(\mathrm{Cu}, \mathrm{Zn}, \mathrm{Ni}, \mathrm{Cd})$ content in the soil/sludge samples was determined after $\mathrm{HNO}_{3} / \mathrm{H}_{2} \mathrm{O}_{2}$ 
digestion. The bioavailable metal fractions were extracted with $0.01 \mathrm{M} \mathrm{CaCl}_{2}$ (pH 7.0) and passed through $0.45-\mu \mathrm{m}$ filter paper. Both the total (digested samples) and the bioavailable metal fractions were analysed using cold vapour atomic absorption spectrometry (CVAAS) with inductively coupled plasma optical emission spectroscope (ICP-OES).

\subsection{Enzyme activity in soil}

The soil hydrolytic enzyme and urease activities were assessed according to Adam and Duncan (2001) and Tabatabai and Bremner (1972), respectively. The activity of the alkaline and acid phosphatases was assessed as described by Tabatabai and Bremner (1969). The nitrification potential was determined using the method of Kandeler (1995).

\subsection{Enumeration of the cultivable bacteria in soil and sewage sludge}

The total cultivable oligotrophic bacteria were enumerated on 0.1 TSA (tryptic soy agar) plates (dilution $10^{-5}-10^{-8}$ ), and the metal-resistant $(\mathrm{CdR}, \mathrm{CuR}, \mathrm{ZnR}, \mathrm{NiR})$ (dilution $10^{-1}-10^{-4}$ ) bacteria were grown on 0.1 TSA media with metals added to a final concentration of $1 \mathrm{mM}, 2 \mathrm{mM}$, $3 \mathrm{mM}$ and $3 \mathrm{mM}$ for $\mathrm{Cd}, \mathrm{Ni}, \mathrm{Zn}$ and $\mathrm{Cu}$, respectively. In addition, the number of tetracycline- and ampicillin-resistant (AmpR, TetR) bacteria was determined on Mueller-Hinton agar supplemented with either ampicillin $\left(100 \mu \mathrm{g} \mathrm{mL}^{-1}\right)$ or tetracycline $\left(10 \mu \mathrm{g} \mathrm{mL}^{-1}\right)$ (dilution $\left.10^{-2}-10^{-4}\right)$. To inhibit fungal growth to all media, nystatin was added at final concentration $50 \mu \mathrm{g} \mathrm{mL}^{-1}$. The plates were incubated at $28^{\circ} \mathrm{C}$ for 7 days. The bacteria were counted in triplicate for each sample.

\subsection{Analysis of the soil microbial community structure using the PLFA method}

The soil microbial community structure and biomass were assessed using a phospholipid fatty acid (PLFA) analysis. Lipids were extracted from $2 \mathrm{~g}$ of soil as was described by Pennanen et al. (1996) and separated using silica extraction columns. The phospholipids were subjected to a mild alkaline methanolysis, and the obtained fatty acid methyl esters (FAMEs) were separated and detected using gas chromatography. The FAMEs were identified using the MIDI Microbial Identification System software (Sherlock 6.0; MIDI Inc.). For the quantitative determination of the PLFA, 19:0 was used as the internal standard. The total biomass (TotPLFA) was calculated as the sum of all the extracted from soil PLFAs (Frostegård and Bååth 1996). The bacterial biomass of gram-negative bacteria was calculated as the sum of the unsaturated, hydroxylated and cyclopropane fatty acids. For the gram-positive bacteria, both iso and anteiso branched fatty acid were counted (Supplementary Table S1). The 10Me16:0, 10Me17:0 and 10Me18:0 were used to establish the biomass of Actinomycetes. The sum of these biomarkers was used to determine the bacterial PLFA biomass. The

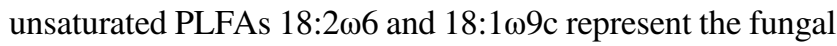
biomass (Zelles 1999).

\subsection{Community-level physiological profiles}

Community-level physiological profiles (CLPPs) were determined using the BIOLOG method and EcoPlate ${ }^{\mathrm{TM}}$ (Biolog Inc.). Briefly, microorganisms were extracted from a 10-g dry weight (d.w.) equivalent of fresh soil in a $0.85 \% \mathrm{NaCl}$ solution and inoculated on an EcoPlate ${ }^{\mathrm{TM}}$. The plates were incubated at $24{ }^{\circ} \mathrm{C}$ under dark, humid conditions. Readings were taken at $590 \mathrm{~nm}$ directly after the inoculation and at 12-h intervals for $72 \mathrm{~h}$ using a microplate reader. The following microbial indices, the functional diversity index $\left(H^{\prime}\right)$, substrate richness (Rs), which reflects the number of oxidized $C$ substrates, and evenness $\left(I^{\prime}\right)$, which corresponds to the equitability of activity across all utilized substrates, were calculated as described elsewhere (Garland and Mills 1991; Cycoń et al. 2013).

\subsection{DNA isolation and real-time quantitative PCR analysis}

Total bacterial DNA was isolated from a 0.25-g (fresh weight) soil/sludge sample in triplicate using a DNeasy® PowerSoil ${ }^{\circledR}$ Kit following the manufacturer's protocol (Qiagen). Real-time PCR was performed using the specific primers MF341 and MR907 (Supplementary Table S2) to quantify the 16S rRNA gene copy number in the soil/sludge samples (Ishii et al. 2000). qPCR was conducted in a mixture of Fast Start Essential DNA Green Master PCR Mix with SYBR Green (Roche), $0.2 \mu \mathrm{M}$ of each primer and $1 \mu \mathrm{L}$ of 10-100-fold diluted DNA with the amplification protocol described previously (Markowicz et al. 2021).

\subsection{Exogenous isolation and transformation of plasmid DNA}

Modified exogenous plasmid isolation was conducted according to Adamczuk et al. (2015). Briefly, $10 \mathrm{~g}$ of a sludge sample was diluted in $90 \mathrm{~mL}$ sterile saline containing Tween and placed on a shaker (120 rpm, $60 \mathrm{~min}, \mathrm{RT})$. One millilitre of the dilution was transferred to $50 \mathrm{~mL} \mathrm{LB}$ broth amended with either ampicillin or tetracycline and incubated overnight at $28{ }^{\circ} \mathrm{C}$. Cells were harvested from $25 \mathrm{~mL}$ of the culture and subsequently subjected to alkaline lysis (Green and Sambrook 2012). The exposure of bacterial suspension to anionic detergents at alkaline $\mathrm{pH}$ caused the disruption of the cell wall, denaturation of chromosomes and proteins and released the 
plasmid DNA into the supernatant. After the denatured material has been removed by centrifugation, the native plasmid DNA was recovered from the supernatant. The obtained plasmid DNA was then analysed on $1 \%$ agarose gels. Plasmid DNA was transformed to Escherichia coli DH5 $\alpha$ using a Micropulser Electroporation Apparatus (Bio-Rad) according to the manufacturer's protocol. The cell suspensions were plated on LB agar supplemented with either ampicillin or tetracycline and grown overnight at $37^{\circ} \mathrm{C}$. Random colonies were picked, grown in LB broth with appropriate antibiotic and screened for plasmid DNA using the minipreparation procedure (Green and Sambrook 2012).

\subsection{Susceptibility/resistance testing}

Antibiotic and metal resistance profiles conferred by the plasmids to E. coli $\mathrm{DH} 5 \alpha$ were assessed using Oxoid M.I.C. Evaluator ${ }^{\mathrm{TM}}$ strips and Mueller-Hinton agar according to the manufacturer's protocol. The, following antibiotics were used in the test: amikacin, ampicillin + sulbactam, cefotaxime, ceftazidime, ceftriaxone, gentamicin, tetracycline, clindamycin, imipenem, levofloxacin and tigecycline. Minimal inhibitory concentrations (MIC) of $\mathrm{Ni}, \mathrm{Zn}$ and $\mathrm{Cu}$ were determined on LB agar plates containing appropriate metals. The E. coli DH5 $\alpha$ strain without a plasmid was used as the control. The tests were performed in duplicate.

\subsection{PCR detection of resistance determinants}

The presence of genes coding for the resistance to ampicillin (bla $a_{T E M-1}, b l a_{N P S-2}$, imp-2, imp-13, ampC, oxa-75), tetracycline (four variants of tetA, tetBSR, tetD, tet $G$, tet $H$ ) and class 1,2, 3 and clinical class 1 integron integrase genes on the isolated plasmids and in the total DNA isolated from the sewage sludge and soil samples were verified using PCR screening. Moreover, the genes coding for metal resistance, cadmium, zinc and cobalt ( $c z c A)$, mercury (merA), copper ( sewage sludge DNA. All PCR reactions were conducted in a mixture that contained a $10 \times$ Taq reaction buffer (Thermo Scientific), $2 \mathrm{mM} \mathrm{MgCl} 2,0.2 \mathrm{mM}$ of dNTP mix, $1 \mathrm{U}$ of Taq polymerase, the specific primers and $1 \mu \mathrm{L}$ of $10-100$-fold diluted template DNA. The PCR reactions were performed with the following program: $94{ }^{\circ} \mathrm{C}$ for 4 min and 35 cycles of $94{ }^{\circ} \mathrm{C}$ for $1 \mathrm{~min}$, annealing at appropriate temperature for $1 \mathrm{~min}, 72{ }^{\circ} \mathrm{C}$ for $45 \mathrm{~s}$ and a final extension at $72{ }^{\circ} \mathrm{C}$ for $10 \mathrm{~min}$. The sequences of all of the used primers, the amplicon size and the annealing temperatures are presented in Supplementary Table S2. To reduce the generation of falsepositive results, reactions with no template and with the genomic DNA isolated from $E$. coli $\mathrm{DH} 5 \alpha$ were performed. The PCR products were analysed using gel electrophoresis.

\subsection{Statistical analyses}

The obtained data from five independent replications were examined using an analysis of variance (ANOVA) repeated in time (RCB repeated in time). The statistical significance of any differences in the measured data was assessed via a post hoc comparison of the means using the LSD test at $p \leq 0.05$. Any difference between the parameters of the sewage sludge and the control soil was evaluated using the Student's $t$ test. These statistical analyses were performed using the Statistica 10.0 PL software package. For visualisation of trends in soil and microbial parameters during the experiment, a heat map was prepared using the MetaboAnalyst tool (Xia et al. 2009). For this purpose, only parameters with statistically significant changes during the experiment $(p<0.05)$ were used (based on the data from Tables 2 and S3). The analysis was performed based on Euclidean distance. The data obtained from the fertilized soil on a specific day was normalized to the mean from the control soil calculated for a specific sampling time. The autoscale features option was used to standardize the data for each feature and to underline by colours any differences in a specific feature value among the sampling times. A canonical correspondence analysis (CCA) was performed to evaluate the effect of the sewage sludge application on the environmental factors and microbial parameters (Past 4 Software). The biplot presented the effect of the environmental factors on the soil profiles was obtained using scaling type 2 . The significance of the correlations with each factor was evaluated through the Monte Carlo permutation test by applying 999 permutations (Hammer et al. 2001).

\section{Results}

\subsection{Characterization of the sewage sludge and soil}

The physicochemical parameters of the sewage sludge and soil are presented in Table 1. The sewage sludge had an alkaline $\mathrm{pH}$ (8.08), and its application caused only a temporary and slight increase $(p<0.05)$ in the $\mathrm{pH}$ value in the FS on day 1 compared to the control unfertilized soil (CS) (Table 2, Fig. 1). The organic matter content was slightly higher in the fertilized soil, but observed differences between the FS and CS were not significant during the entire experiment $(p>0.05)$ The amount of total nitrogen $(\mathrm{N})$ and available phosphorus $(\mathrm{P})$ in sewage sludge was about $7.5 \%$ and $1.1 \%$, respectively. No significant increase in nutrient content was observed in the fertilized soil compared to the control soil (Table 3). The control soil was characterized by a high total content of $\mathrm{Cd}$ and $\mathrm{Zn}$ (Table 1) whose reported values were $21.0 \pm 2.2$ and $2595 \pm 317 \mathrm{mg} \mathrm{kg}^{-1}$ d.w. soil for $\mathrm{Cd}$ and $\mathrm{Zn}$, respectively. The total content of $\mathrm{Cd}, \mathrm{Zn}, \mathrm{Cu}$ and $\mathrm{Ni}$ in the 
Table 1 Physicochemical parameters of sewage sludge and soil

\begin{tabular}{|c|c|c|}
\hline Properties & Sewage sludge & Control soil \\
\hline $\mathrm{pH}$ & $8.1 \pm 0.1 \mathrm{a}$ & $7.1 \pm 0.1 \mathrm{~b}$ \\
\hline Moisture (\%) & $78.7 \pm 3.5 \mathrm{a}$ & $10.3 \pm 1.2 \mathrm{~b}$ \\
\hline $\mathrm{OM}(\%)$ & $56.3 \pm 1.8 \mathrm{a}$ & $13.9 \pm 0.7 \mathrm{~b}$ \\
\hline Conductivity $\left(\mathrm{mS} \mathrm{cm}^{-1}\right)$ & $220.0 \pm 1.0 \mathrm{a}$ & $0.27 \pm 0.11 b$ \\
\hline Total $\mathrm{Zn}\left(\mathrm{mg} \mathrm{kg}^{-1}\right)$ & $805.6 \pm 419.7 \mathrm{~b}$ & $2595.1 \pm 317.3 \mathrm{a}$ \\
\hline Total Cd $\left(\mathrm{mg} \mathrm{kg}^{-1}\right)$ & $9.0 \pm 3.4 \mathrm{~b}$ & $21.0 \pm 2.2 \mathrm{a}$ \\
\hline Total $\mathrm{Cu}\left(\mathrm{mg} \mathrm{kg}^{-1}\right)$ & $226.8 \pm 71.1 \mathrm{a}$ & $31.6 \pm 1.8 \mathrm{~b}$ \\
\hline Total Ni (mg kg $\left.{ }^{-1}\right)$ & $1.9 \pm 0.3 \mathrm{a}$ & $1.6 \pm 0.5 \mathrm{a}$ \\
\hline Bioavailabile $\mathrm{Cd}\left(\mathrm{mg} \mathrm{kg}^{-1}\right)$ & $1.5 \pm 0.3 \mathrm{a}$ & $0.2 \pm 0.1 \mathrm{~b}$ \\
\hline Bioavailabile $\mathrm{Zn}\left(\mathrm{mg} \mathrm{kg}^{-1}\right)$ & $6.8 \pm 1.1 \mathrm{a}$ & $4.1 \pm 1.7 \mathrm{~b}$ \\
\hline Bioavailabile $\mathrm{Cu}\left(\mathrm{mg} \mathrm{kg}^{-1}\right)$ & $3.5 \pm 0.2 \mathrm{a}$ & $0.2 \pm 0.0 \mathrm{~b}$ \\
\hline Bioavailabile Ni $\left(\mu \mathrm{g} \mathrm{kg}^{-1}\right)$ & $435.6 \pm 26.1 \mathrm{a}$ & $12.3 \pm 2.6 \mathrm{~b}$ \\
\hline $\log$ 16S rRNA g.c.n & $12.7 \pm 0.4 \mathrm{a}$ & $11.0 \pm 0.4 \mathrm{~b}$ \\
\hline $\log$ CFU oligotrophic & $9.7 \pm 0.6 \mathrm{a}$ & $8.6 \pm 0.8 b$ \\
\hline $\log \mathrm{CFU} \mathrm{Ni}{ }^{\mathrm{R}}$ & $6.1 \pm 0.3 \mathrm{a}$ & $5.1 \pm 0.2 b$ \\
\hline $\log \mathrm{CFU} \mathrm{Cu}{ }^{\mathrm{R}}$ & nd & $3.4 \pm 0.2$ \\
\hline $\log \mathrm{CFU} \mathrm{Cd} \mathrm{d}^{\mathrm{R}}$ & $5.2 \pm 0.1 \mathrm{a}$ & $3.8 \pm 0.3 b$ \\
\hline $\log \mathrm{CFU} \mathrm{Z \textrm {n } ^ { \mathrm { R } }}$ & $6.9 \pm 0.2 \mathrm{a}$ & $6.2 \pm 0.1 \mathrm{~b}$ \\
\hline $\log$ CFU Tetr ${ }^{R}$ & $8.0 \pm 0.1 \mathrm{a}$ & $6.4 \pm 0.3 b$ \\
\hline $\log \mathrm{CFU} A m p^{\mathrm{R}}$ & $8.0 \pm 0.2 \mathrm{a}$ & $7.8 \pm 0.3 b$ \\
\hline
\end{tabular}

The 16S rRNA is expressed in $\log 10$ gene copy number $\mathrm{g}^{-1}$ dry soil or sewage sludge; the number of cultivable bacteria is expressed in $\log 10$ of colony-forming units $\mathrm{g}^{-1}$ of dry soil or sewage sludge. Average values $(n=5)$ are represented \pm SD. Significant changes between control soil and sewage sludge are indicated by different letters $n d$ not detected

sewage sludge was low and did not affect the metal content in the FS compared to the CS (data not shown). The addition of the sewage sludge into the soil slightly increased the bioavailable content of $\mathrm{Cd}, \mathrm{Cu}$ and $\mathrm{Ni}$ (the main effect, $p<0.05, p<0.001$ and $p<0.001$, respectively). Additionally, significant changes $(p<0.001)$ in the content of bioavailable Ni were observed at days 1 and 360 during the experiment (Table 2).

\subsection{Microbial populations, composition and activity}

The total bacteria quantified as a 16S rRNA gene copy number (g.c.n.) was about one order of magnitude higher in the sewage sludge ( $12.7 \pm 0.4$ g.c.n. $g^{-1}$ d.w. sewage sludge, Table 1) compared to the control soil. The addition of the sewage sludge caused differences between the FS and CS $(p<0.05)$. During the first 180 days of the experiment, the 16S rRNA g.c.n. was higher in the CS than in the FS, but after that time point, the opposite trend was noticed and significant changes were observed at day 540 (Fig. 1, Supplementary Table S3). In the cultivable microbial population, there were significant differences between the CS and the FS for bacteria resistant to $\mathrm{Cd}(\mathrm{CdR}), \mathrm{Cu}(\mathrm{CuR}), \mathrm{Ni}(\mathrm{NiR})$, tetracycline (TetrR) and ampicillin (AmpR) during the experiment. All of the aforementioned cultivable bacterial fractions had lower values in the FS compared to the CS at day 1 . The only exception was observed for CuR bacteria in which no differences were observed at day 1 , while a lower number of these bacteria were discovered in the FS at day 360. The number of NiR bacteria was lower in the FS compared to the CS until the day 360 of the experiments, whereas the number of CdR bacteria was lower in the FS compared to the CS at the end of the experiment (days 360 and 540). Significant differences were observed for the AmpR bacteria at day 180 on which there were more of these bacteria in the FS compared to the CS.

Generally, the biomass of microorganisms, measured as the sum of all isolated from the soil phospholipid fatty acids (total PLFAs), and the bacterial and fungal biomass, which was quantified based on the PLFAs biomarkers, was significantly lower $(p<0.001)$ in the FS compared to the CS (Fig. 1, Supplementary Table S3). The functional diversity of the microbial communities in the soils, assessed using the Biolog method, revealed significant changes in the diversity $\left(H^{\prime}\right)$, the evenness $\left(I^{\prime}\right)$ and the richness (Rs) indices during the experiment (Fig. 1, Supplementary Table S3). There were significantly higher values of $H^{\prime}$ and $I^{\prime}$ indices in the FS than the CS on days 180 and 360. At the end of the experiment, all of the analysed indices were significantly lower in the FS than in the CS. Dose and time interaction has also significant impact $(p<0.001)$ on the microbial activity, expressed as average well colour development (AWCD) on Biolog EcoPlates ${ }^{\mathrm{TM}}$. Post hoc test revealed significant changes between the FS and the CS at the end of the experimental period. The value of AWCD was higher in the FS on day 360 and was the lowest at the end of the experiment (day 540). Among the tested enzyme activity, the hydrolytic activity (FDAH), alkaline and acid phosphatase activity changed significantly $(p<0.05, p<0.001)$ between the FS and CS during the experiment. The hydrolytic and acid phosphatase activity was significantly higher in the FS compared to the CS on day 1. During the experiment, both the acid and alkaline phosphatase activities were significantly lower in the FS compared to the CS, while there were no significant differences in the urease activity and nitrification potential.

Canonical correspondence analysis was used to identify the most important environmental factors that affected the microbial parameters in the tested soils (Fig. 2). The microbial profiles of the FS were clearly different than those from the CS during the 540-day experiment. The identified factors that had an effect in the FS were the increased bioavailable $\mathrm{Ni}, \mathrm{Cu}$ and $\mathrm{Cu}$ content and the decreased bioavailable $\mathrm{Zn}$ content. These factors significantly affected the microbial biomass, alkaline phosphatase and urease activity. 


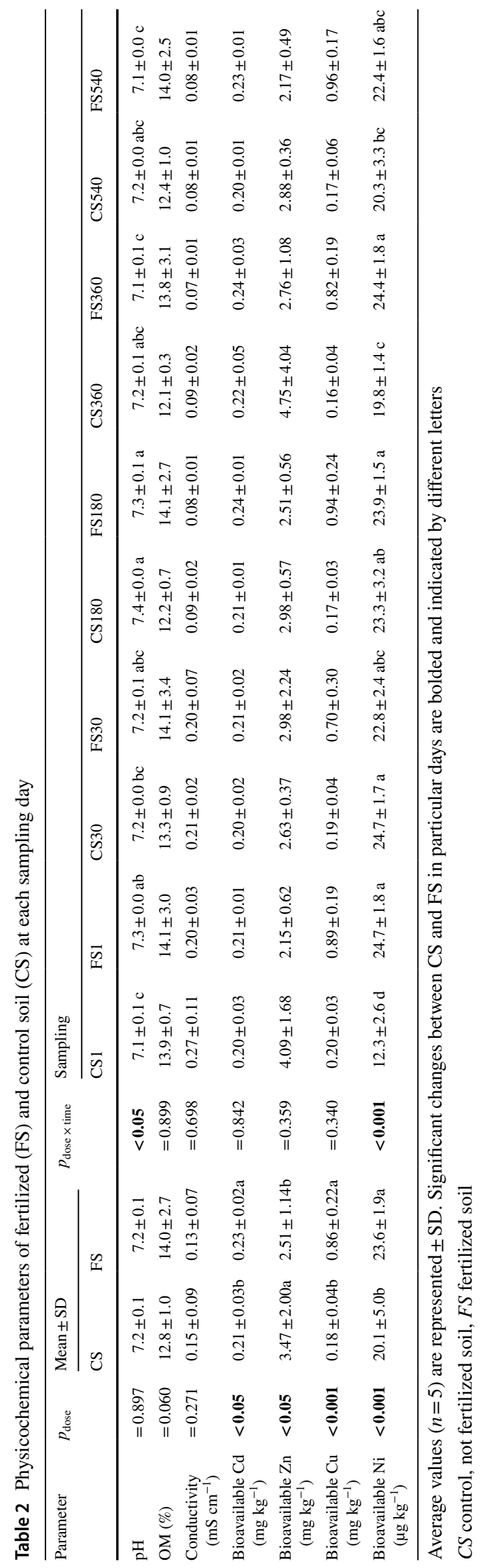


Fig. 1 Heat map showing the effects of sewage sludge application on soil microbial characteristics. Data at each sampling point represent the ratio of the mean parameters obtained from the fertilized soil to the control. Only the parameters that significantly $(p<0.05)$ changed during the experiment were used to create the heat map. The significant ratio values are presented. The red-blue range of colours indicates the data scaling for each feature in order to stress the differences in the values among the sampling times. For details, please refer to Table 2 and Supplementary Table S2

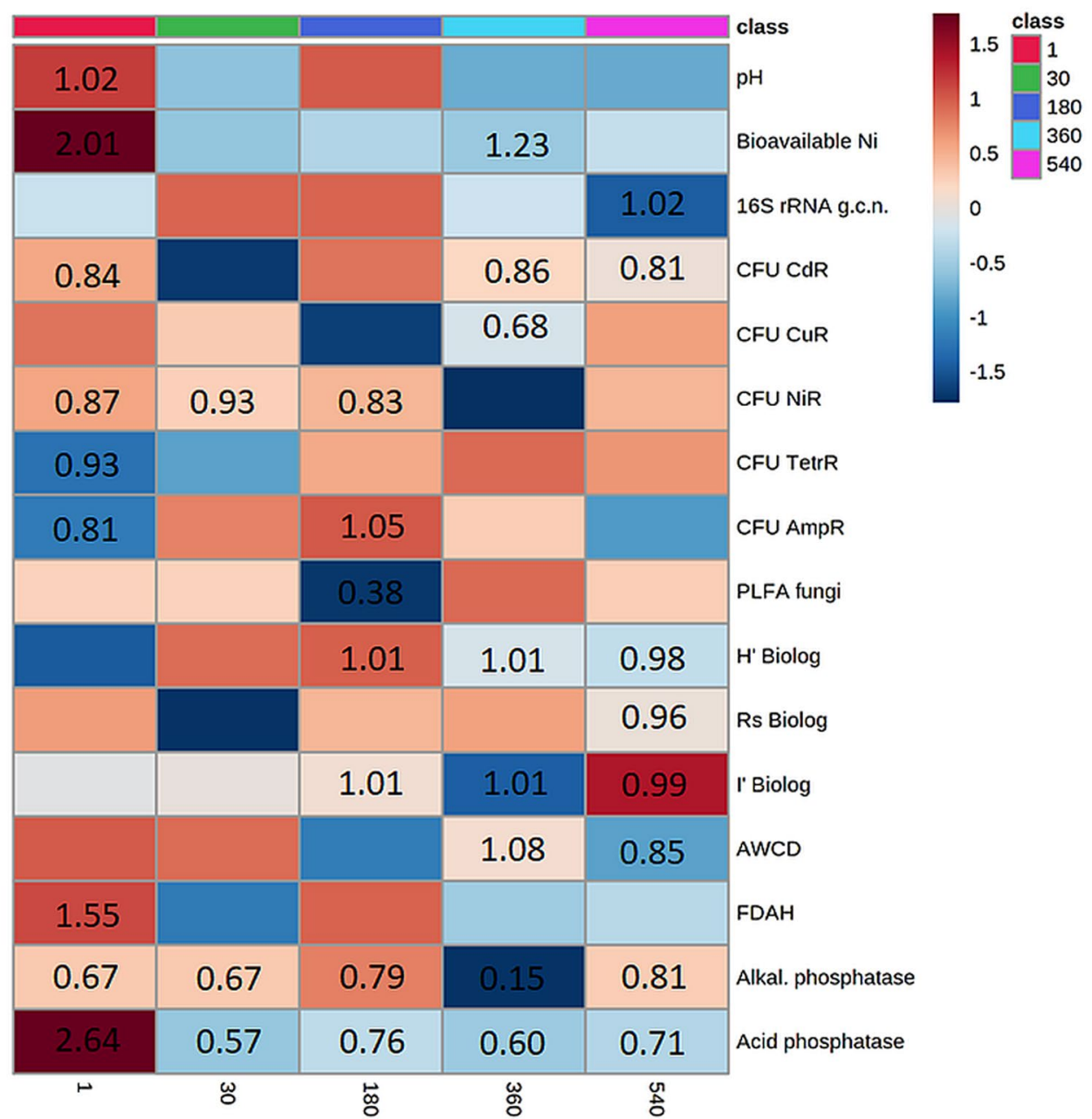

\subsection{Sewage sludge resistome}

Resistance plasmids were isolated from sewage sludge and transformed into $E$. coli $\mathrm{DH} 5 \alpha$. Sixty transformants were screened for plasmid DNA, and 10 plasmids were selected for further studies based on an electrophoretic analysis. Of the tested plasmids, seven were ampicillin resistance

Table 3 Nutrient content analysis in sewage sludge, fertilized and control soils

\begin{tabular}{lllll}
\hline $\begin{array}{l}\text { Proper- } \\
\text { ties }\end{array}$ & $p$ value & $\begin{array}{l}\text { Sewage } \\
\text { sludge }\end{array}$ & Control soil & Fertilized soil \\
\hline $\begin{array}{c}\text { Total N } \\
(\%)\end{array}$ & $<0.001$ & $7.54 \pm 1.82 \mathrm{a}$ & $0.54 \pm 0.03 \mathrm{~b}$ & $0.43 \pm 0.09 \mathrm{~b}$ \\
$\begin{array}{c}\text { Available } \\
\mathrm{P}(\%)\end{array}$ & $<0.001$ & $1.09 \pm 0.24 \mathrm{a}$ & $0.04 \pm 0.002 \mathrm{~b}$ & $0.04 \pm 0.006 \mathrm{~b}$ \\
$\begin{array}{c}\text { Organic } \\
\mathrm{C}(\%)\end{array}$ & $<0.001$ & $32.67 \pm 1.06 \mathrm{a}$ & $8.08 \pm 0.39 \mathrm{~b}$ & $8.17 \pm 1.76 \mathrm{~b}$ \\
$\mathrm{C} / \mathrm{N}$ & $<0.05$ & $4.51 \pm 0.98 \mathrm{~b}$ & $14.51 \pm 0.23 \mathrm{a}$ & $16.78 \pm 4.26 \mathrm{a}$ \\
\hline
\end{tabular}

Average values are represented \pm SD plasmids (pOA1-pOA7) and three were tetracycline resistance plasmids (pOT1-pOT3) (Table 4). A bla $a_{T E M-1}$ gene, which encodes class A $\beta$-lactamase, was detected in all of the ampicillin resistance plasmids. Multi-drug resistance was confirmed for plasmids pOA3, pOA4 and pOA7 using the $E$ test. All three plasmids confer resistance to ceftazidime $\left(0.25 \mu \mathrm{g} \mathrm{mL}^{-1}\right)$ and ceftriaxone at concentrations ranging from 1.0 to as high as $2.0 \mu \mathrm{g} \mathrm{mL}^{-1}$ for pOA4, which was more than 130-fold higher than the minimum inhibitory value for the E. coli $\mathrm{DH} 5 \alpha$ recipient strain (Table 4). We did not detect any resistance to amikacin, imipenem, clindamycin or tigecycline. The isolated plasmids pOT2 and pOT3 conferred resistance to tetracycline at concentrations $>256 \mu \mathrm{g} \mathrm{mL}^{-1}$, the maximum concentration for the commercially available strips. The plasmid pOT1 conferred resistance to tetracycline at a concentration of $96 \mu \mathrm{g} \mathrm{mL}$. No resistance to other antibiotics was detected.

Among the tetracycline resistance plasmids, the gene responsible for resistance was only identified on plasmid pOT3. This was a tet $H$ gene, which encodes a tetracycline efflux pump. Class 1 and 3 integron integrase genes were 


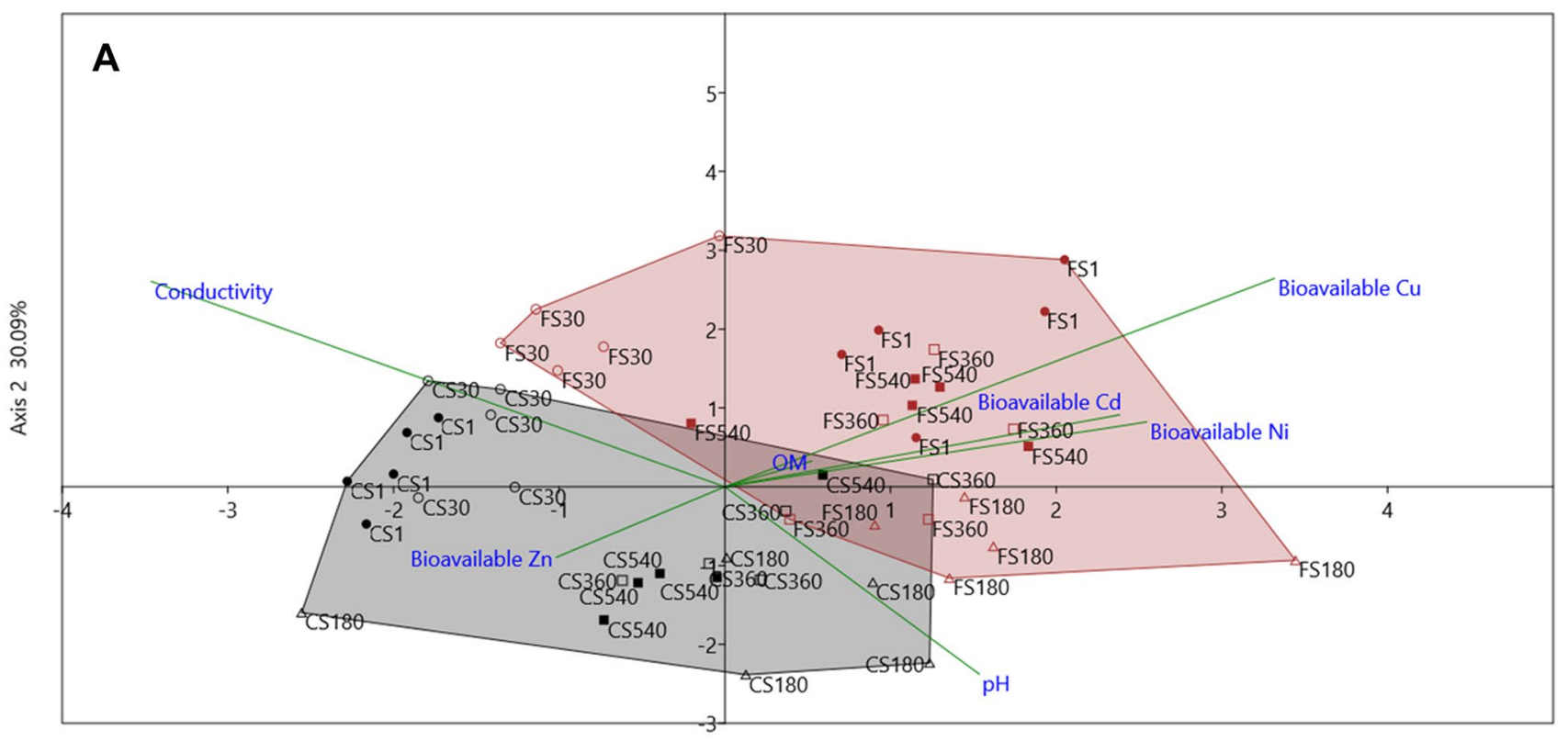

Axis $150.11 \%$

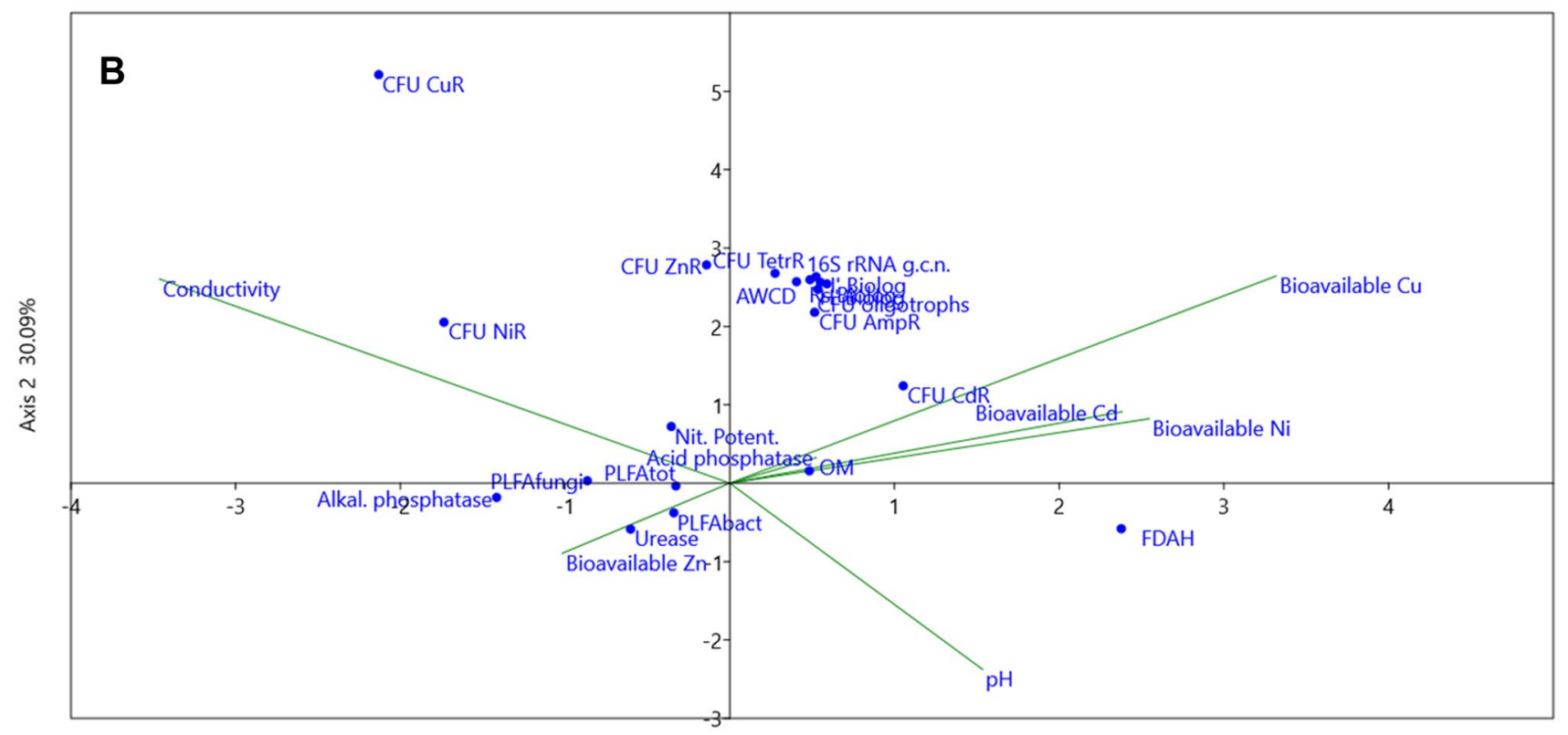

Axis $150.11 \%$

Fig. 2 Canonical correspondence analysis (CCA) of soil profiles in the fertilized (FS) and the control (CS) soils. The biplots present the effect of the environmental factors on the soil profiles (a) and their

detected on plasmid pOT1. Moreover, the clinical class 1 integron integrase gene (int $1 K L$ ), which is linked to genes conferring resistance to disinfectants, antibiotics and metals, was detected on plasmids pOT1 and pOA6. Isolated plasmids conferred no metal $(\mathrm{Cu}, \mathrm{Ni}, \mathrm{Zn})$ and antibiotic coresistance. However, MRGs and ARGs were detected in the DNA isolated from the sewage sludge (Table 5). Resistance correlation with the microbial parameters (b). Symbols: dots, day 1; circle, day 30; triangle, day 180 ; square, day 360 ; filled square, day 540

genes, including five $\beta$-lactam resistance genes ( bla $_{N P S-2}$, bla $a_{T E M-1}$, imp-2, imp-13, ampC), six tetracycline resistance genes (tet $A 1-A 4$, tet $G$, tet $H$ ) and five MRGs conferring resistance to $\mathrm{Hg}$ (merA), $\mathrm{Cd}, \mathrm{Zn}, \mathrm{Co}(c z c A), \mathrm{Cu}(\operatorname{cop} A, c o p B)$ and $\mathrm{Ni}(n c c A / N)$ were detected in the sewage sludge using PCR. Moreover, class 1, 2, 3 and clinical class 1 integron integrase genes were detected in the sewage sludge DNA. 
Table 4 Characterization of isolated plasmids

\begin{tabular}{|c|c|c|c|c|}
\hline Plasmid & Resistance to antibiotics & & Detected ARGs & $\begin{array}{l}\text { Detected integron } \\
\text { integrase genes }\end{array}$ \\
\hline pOA1 & Ampicilin $100 \mu \mathrm{g} \mathrm{mL}^{-1}$ & - & $b l a_{T E M-1}$ & - \\
\hline pOA2 & Ampicilin $100 \mu \mathrm{g} \mathrm{mL}^{-1}$ & - & $b l a_{T E M-1}$ & - \\
\hline pOA3 & Ampicilin $100 \mu \mathrm{g} \mathrm{mL}^{-1}$ & Ceftriaxone $1 \mu \mathrm{g} \mathrm{mL}^{-1}$ ceftazidime $0.25 \mu \mathrm{g} \mathrm{mL}^{-1}$ & $b_{\text {TEM-1 }}$ & - \\
\hline pOA4 & Ampicilin $100 \mu \mathrm{g} \mathrm{mL}^{-1}$ & Ceftriaxone $2 \mu \mathrm{g} \mathrm{mL}^{-1}$ ceftazidime $0.25 \mu \mathrm{g} \mathrm{mL}^{-1}$ & $b l a_{T E M-1}$ & - \\
\hline pOA5 & Ampicilin $100 \mu \mathrm{g} \mathrm{mL}^{-1}$ & - & $b l a_{T E M-I}$ & - \\
\hline pOA6 & Ampicilin $100 \mu \mathrm{g} \mathrm{mL}^{-1}$ & - & $b l a_{T E M-1}$ & int $1 K L$ \\
\hline pOA7 & Ampicilin $100 \mu \mathrm{g} \mathrm{mL}{ }^{-1}$ & Ceftriaxone $1 \mu \mathrm{g} \mathrm{mL}^{-1}$ ceftazidime $0.25 \mu \mathrm{g} \mathrm{mL}^{-1}$ & $b_{\text {TEM-1 }}$ & - \\
\hline pOT1 & Tetracycline $96 \mu \mathrm{g} \mathrm{mL}^{-1}$ & - & - & int 1 , int $1 K L$, int 3 \\
\hline pOT2 & Tetracycline $\geq 256 \mu \mathrm{g} \mathrm{mL}^{-1}$ & - & - & - \\
\hline pOT3 & Tetracycline $\geq 256 \mu \mathrm{g} \mathrm{mL}^{-1}$ & - & tetH & - \\
\hline
\end{tabular}

\subsection{Soil resistome}

Two $\beta$-lactam resistance genes $b l a_{T E M-1}$ and imp-2 and tetracycline resistance gene tet $G$ were detected in sewage sludge as well as in the fertilized and unfertilized control soil (Table 5). Two genes, $b l a_{N P S-2}$ and tetA2, present in sewage sludge were detected in the fertilized soil until day 180. Moreover, another gene (tetA4) was detected in the fertilized soil at the first two sampling points. Among the MRGs, only the $c z c A$ gene was present in sewage sludge and both soils. None of other four MRGs amplified in the total DNA from sewage sludge was amplified in fertilized soil. Among the identified in sewage sludge integrase genes, only the class 1 integron integrase gene was detected in the fertilized soil at day 30 (Table 5).

\section{Discussion}

\subsection{The impact of the sewage sludge on the soil physicochemical and microbial properties}

Previous studies demonstrated that repeated for several years' application and/or large, often unrealistic quantities of sewage sludge causes the increase in soil organic matter (OM) and plant nutriens (N, P, K) (Hamdi et al. 2019; Urra et al. 2019). In our study, the sewage sludge was characterized by high OM content and acceptable for a fertilizer content of plant nutrients: $\mathrm{N}, \mathrm{P}$ and $\mathrm{C} / \mathrm{N}$ ratio. The ANOVA analysis revealed that solely the organic carbon and $\mathrm{C} / \mathrm{N}$ ratio were slightly higher in the fertilized soil, but observed differences were not significant; therefore, the fertilization

Table 5 Antibiotic resistance genes (ARGs), metal resistance genes (MRGs) and integron integrase genes detected in sewage sludge and soils at each sampling day

\begin{tabular}{|c|c|c|c|c|c|}
\hline \multirow[b]{2}{*}{ Sewage sludge } & \multicolumn{2}{|c|}{ Detected antibiotic resisatnce genes (ARGs) } & \multicolumn{2}{|c|}{ Detected MRGs } & \multirow{2}{*}{$\begin{array}{l}\text { Detected MGEs } \\
\text { int } 1, \text { int } 2, \text { int } 3 \text {, int } 1 K L\end{array}$} \\
\hline & bla $_{T E M-1}$, imp-2, tet $G$ & $\begin{array}{l}\text { bla }_{N P S-2}, \text { imp-13, ampC, tetA1, } \\
\text { tetA2, tetA3, tetA4, tetH }\end{array}$ & $c z c A$ & $\begin{array}{l}\text { merA, } c z c A, \operatorname{cop} A, \\
\operatorname{cop} B, n c c A / N\end{array}$ & \\
\hline & Shared* & Transferred $* *$ & Shared* & Transferred ${ }^{* *}$ & Transferred** \\
\hline $\begin{array}{l}\text { CS1 } \\
\text { CS30 } \\
\text { CS180 } \\
\text { CS360 } \\
\text { CS540 }\end{array}$ & bla $_{T E M-1}$, imp-2, tet $G$ & - & $c z c A$ & - & - \\
\hline $\begin{array}{l}\text { FS1 } \\
\text { FS30 }\end{array}$ & $b l a_{T E M-1}$, imp-2, tet $G$ & $b l a_{N P S-2}$, tetA2, tetA4 & $c z c A$ & - & $\overline{-}$ \\
\hline FS180 & & bla $_{N P S-2}$, tetA2 & & & $\overline{-}$ \\
\hline FS360 & & - & & & - \\
\hline FS540 & & - & & & - \\
\hline
\end{tabular}

MGEs mobile genetic elements

*Genes detected in sewage sludge and all soil samples

** Genes detected only in the fertilized soil, transferred from sewage sludge 
effects were not achieved. The relatively low sewage sludge dose and a single application may have been why there was no significant increase in $\mathrm{OM}$ and nutrient content. Some authors observed in fertilized soils the increase of enzymatic activity, which correlated with the number of sewage sludge applications (Roig et al. 2012; Arif et al. 2018). In our study, the hydrolytic and acid phosphatase activity in the treated soil was higher than in the control soil at the beginning of the experiment. Afterwards, both the acid and alkaline phosphatase activity were significantly lower in the sewage sludge-treated soil. The initial increase in enzymatic activity can be explained by the organic substances' supply prone to enzymatic hydrolysis. Such explanation was also proposed by Protano et al. (2020), who suggested that $\mathrm{OM}$ in sewage sludge mainly consists of easily degradable organic compounds that are quickly degraded and do not accumulate in soil even when unrealistic and extremely high levels of sewage sludge are applied (Kirchmann et al. 2017; Protano et al. 2020). On the other hand, the positive effect may have been counteracted by the presence of metals or other toxicants in sewage sludge. The current requirements in European Union (EU) legislation have focused only on the presence of total content of heavy metals in sewage sludge and soil (Commission of European Communities 1986; European Commission 2010). In our study, the total concentration of $\mathrm{Cd}, \mathrm{Zn}, \mathrm{Cu}$ and $\mathrm{Ni}$ in the sewage sludge did not exceed the recommended guidelines. Considering only this requirement, the sewage sludge might be regarded as a valuable and safe soil fertilizer. The other precautions in EU policy are connected with heavy metals in soil to which sewage sludge can be applied (European Commission 2010). In our study, of the tested metals, the initial total content of $\mathrm{Cd}$ and $\mathrm{Zn}$ in the soil was above the proposed limits. Although elevated metal contents in agricultural soils are not desirable for food production, high concentrations of heavy metal can be detected in soil at a regional level (Tóth et al. 2016). In our study, high content of metals is related with the history of Upper Silesia because it is a post-industrial area where mining and coal processing plants have been in operation for many years (Dudka et al. 1995).

It is well known that for risk assessment, the bioavailable metal fraction is more critical than the total content because bioavailable metal fraction is accessible to plants and microorganisms (Alloway 2012). In our study, a significant increase in bioavailable metal content in fertilized soil was observed only for nickel. For bioavailable $\mathrm{Cd}$ and $\mathrm{Cu}$ ANOVA indicated the increase only as the main effect (Fig. 1, Table 2). Additionally, the CCA clearly distinguished the control and fertilized soils as separate clusters (Fig. 2). This analysis revealed that sewage sludge caused alternations in the microbial community. We speculate that the cumulative effect of changes in the bioavailable metal content $(\mathrm{Cu}, \mathrm{Cd}, \mathrm{Ni}, \mathrm{Zn})$ was the main driver that impacted the microbial communities in fertilized soil. This observation was hardly expressed based on ANOVA. It should be considered that sewage sludge may be a source of bioavailable metals and/or cause changes in environmental conditions that affect metal bioavailability. For example, biodegradation of sewage sludge organic compounds may lead to soil acidification (Protano et al. 2020). Moreover, the increased content of heavy metals may be toxic for plants and may exert selective pressure on the soil microorganisms, thereby decreasing their diversity and leading to the proliferation of metal-resistant bacteria. In our study, the high initial number of metal- and antibiotic-resistant bacteria in the control soil indicated a notable and diverse pool of soil resistance (Monier et al. 2011). Although the number of cultivable metal- and antibiotic-resistant bacteria was higher in the sewage sludge compared to the soil, there was no significant increase of these bacterial fractions in the fertilized soil compared to the non-fertilized soil. Similarly to the lack of significant organic matter increase, it may be explained by a relatively low dose and a single application of sewage sludge. Moreover, another aspect of sewage sludge application is the incorporation of sludge-borne microorganisms to soil and the increase in the number of microorganisms and microbial activity. Unexpectedly, the decrease in the number of cultivable fraction of metal-resistant bacteria in response to sewage sludge application was observed for some time points. Our results may suggest that sludge-borne bacteria, including metal- and antibiotic-resistant, rapidly died off in soil because of the high competition with soil bacteria and/or soil conditions that were not favourable for the proliferation of sludge-borne bacteria (Jamieson et al. 2002; Ellis et al. 2018). Similar die-off of sewage sludge incorporated microorganisms was observed by Hamdi et al. (2019), who found no faecal coliform in soil after three successive annual sludge amendments with high doses of sewage sludge (40-120 $\mathrm{tha}^{-1}$ year $\left.^{-1}\right)$. Another explanation may be possible contamination of fertilized soil with other than heavy metals and toxic compounds present in sewage sludge (Östman et al. 2017; da Silva Souza et al. 2020). Even though sewage sludge addition did not elevate the level of cultivable soil bacteria or biomass, there was a significant increase in microbial diversity. These effects were temporary and only lasted for a year, and at the end of the experiment, a biodiversity decline in sewage sludge treated soil compared to the control soil was observed. These observations may be explained by the sewage-delivered organic matter turn-over, which facilitates the diversity of bacteria.

\subsection{Sewage sludge resistome}

Ampicillin and tetracycline resistance were selected for our study since both antibiotics are broadly and frequently used to treat bacterial infections in humans and veterinary practice 
(Kim et al. 2011; Bush and Bradford 2016). Both tetracycline and ampicillin resistance genes were often found in WWTPs, sewage sludge and anthropogenic impacted soil (Makowska et al. 2016; Jang et al. 2018). The $b l a_{T E M-1}$ gene detected on the plasmids isolated in our study encodes a class A $\beta$-lactamase, an enzyme that cleaves the $\beta$-lactam ring responsible for the antimicrobial activity of the $\beta$-lactam antibiotics. To date, there are known more than 100 variants of TEM $\beta$-lactamase, which are present on various number of resistance and multi-resistance plasmids (Partridge and Hall 2005; Pagaling et al. 2016). The expansion of the substrate spectrum of the broad-spectrum TEM-type $\beta$-lactamases led to the development of resistance to cephalosporins, such as detected on the plasmids isolated in this study (Pfeifer et al. 2010). $\mathrm{TetH}$ identified on the plasmid and other tet genes detected in sewage sludge encode the tetracycline efflux pumps that belong to the major facilitator superfamily (MFS) of the multi-drug efflux system (Poole 2005). Resistance to antibiotics is often co-selected with metal resistance, and resistance genes may be present on bacterial chromosomes or mobile genetic elements such as plasmids. In addition, plasmids often carry integrons which are genetic elements that can capture genes and transfer them inside a bacterial cell or horizontally between different species (Gillings et al. 2015). The presence of the integrase genes detected in the sewage sludge DNA and on the plasmids isolated in our study indicates the prevalence of integrons in sewage sludge bacteria (Makowska et al. 2016; Jang et al. 2018). The clinical class 1 integrons (int $1 K L$ ) are present in many bacteria isolated from clinical and anthropogenic impacted environments (Gillings 2018). Antibiotics or disinfectants used in every household and/or local hospital that was in the catchment of the WWTP probably assembled the selective pressure and explained the presence of int $1 K L$ on the plasmids isolated in our study. It should be taken into account that plasmid studies are biased by several limitations, including difficulties in capturing plasmids or the inability to replicate them in laboratory hosts ( $\mathrm{Li}$ et al. 2015). Our study attempted to directly isolate plasmids from the sewage sludge plasmid metagenome was not successful. To isolate the plasmids, an enrichment step was necessary to transform the plasmids into the recipient strain E. coli DH5 $\alpha$. Even though the plasmid isolation was not efficient, only small plasmids that could pass via the transformation into the recipient strain were captured. Because of this potential limitation, we suggest that other plasmids that carry resistance genes were present in the sewage sludge. This statement may be supported by the fact that the ARGs and MRGs detected in the DNA isolated from the sewage sludge in our study were commonly found on plasmids (Szczepanowski et al. 2009; Che et al. 2019). These findings indicate that sewage sludge may be hazardous waste and that using it as a soil fertilizer especially long-term and at high doses requires careful consideration.

\subsection{The impact of sewage sludge treatment on the soil resistome}

Long-term soil application of sewage sludge leads to the proliferation of ARGs conferring resistance to all of the major classes of antibiotics (Chen et al. 2016; Urra et al. 2019). In our study, three resistance genes were detected in sewage sludge and both soils. Previously described $b a_{T E M-1}$ gene was identified in the mid-1970s, and nowadays, it is still widely detected (Szczepanowski et al. 2009; Pagaling et al. 2016). The second ampicillin resistance gene, imp2 , was first detected in 2000. This gene encodes a class B metallo $\beta$-lactamase, which confers resistance to ampicillin, cephalosporins and carbapenems. These drugs are broadspectrum antibiotics that have activity against gram-negative and gram-positive bacteria, and some of them are the lastresort drugs (Pfeifer et al. 2010). Although the imp-2 gene was previously detected in WWTPs (Szczepanowski et al. 2009), its occurrence in soil is quite alarming (Gudeta et al. 2016). The tet $G$, the third ARG detected in sewage sludge as well as in both soils, is responsible for tetracycline resistance. This gene is considered persistent in soil since it has many potential host bacteria in the soil environment (Cheng et al. 2016; Zhang et al. 2018). As for MRGs, the occurrence in sewage sludge and soil of the $c z c A$ gene, conferring resistance to $\mathrm{Cd}$, Co and $\mathrm{Zn}$, may be related to the high level of heavy metals in these environments. The $c z c A$ gene encodes a resistance nodulation division (RND) type efflux pump, which is an active protection against bioavailable toxic metals for microorganisms (Karelová et al. 2011). Moreover, Di Cesare et al. (2016) found strong correlations between the $c z c A$ gene and both sulphonamide resistance and the class 1 integron integrase genes, suggesting an important antibiotic resistance co-selection mechanism. However, this phenomenon was not observed in our study because the class 1 integron integrase gene was found in the fertilized soil only once- 30 days after the sewage sludge application. The treatment with sewage sludge caused the appearance of the $b l a_{N P S-2}$ gene encoding a class D $\beta$-lactamase and two tetA genes that confer resistance to tetracycline. In our study, these genes were detected in the fertilized soil up to 6 months after the sewage sludge application. Similar findings were reported by Wolters et al. (2019), who observed a decrease in the abundance of all of the targeted ARGs over time. It is possible that a year after the fertilization, these genes were below the detection limit in the fertilized soil because of the lack of host bacteria. Although the application of sewage sludge did not cause the emergence of other ARGs and MRGs in the fertilized soil, these findings should not be over-interpreted since resistance genes may be present in soil in low copy number far below the detection limit of PCR (Fortunato et al. 2018). 


\section{Conclusions}

This study extended the knowledge regarding the contribution of the regulated dose of sewage sludge on the soil microbiome and resistome under field conditions. The application of sewage sludge did not improve the plant nutrients and organic matter contents in soil, and therefore the quality or fertility of tested soil. However, the regulated dose may increase bioavailable metal fractions even when low total metal content sewage sludge was applied. This fact may prevent the fertilization effect of sewage sludge and explain the negligible impact on microbial communities. Moreover, this study demonstrated that sewage sludge was a vast repository of ARGs, MRGs and MGEs. Some of these genes have the potential to be transferred into the soil. These findings provide critical data that have public health implications, which may raise concerns about the suitability of sewage sludge soil application. However, we are aware that the fertilization effect may be soil- and sewage sludge origin-dependent.

Supplementary Information The online version contains supplementary material available at https://doi.org/10.1007/s11368-021-02984-1.

Funding This work was supported by the National Science Centre (NCN), Poland (grant number 2013/11/D/NZ9/02519).

\section{Declarations}

Conflict of interest The authors declare no competing interests.

Open Access This article is licensed under a Creative Commons Attribution 4.0 International License, which permits use, sharing, adaptation, distribution and reproduction in any medium or format, as long as you give appropriate credit to the original author(s) and the source, provide a link to the Creative Commons licence, and indicate if changes were made. The images or other third party material in this article are included in the article's Creative Commons licence, unless indicated otherwise in a credit line to the material. If material is not included in the article's Creative Commons licence and your intended use is not permitted by statutory regulation or exceeds the permitted use, you will need to obtain permission directly from the copyright holder. To view a copy of this licence, visit http://creativecommons.org/licenses/by/4.0/.

\section{References}

Adam G, Duncan H (2001) Development of a sensitive and rapid method for the measurement of total microbial activity using fluorescein diacetate (FDA) in a range of soils. Soil Biol Biochem 33:943-951. https://doi.org/10.1016/S0038-0717(00)00244-3

Adamczuk M, Zaleski P, Dziewit L et al (2015) Diversity and global distribution of IncL/M plasmids enabling horizontal dissemination of $\beta$-lactam resistance genes among the Enterobacteriaceae. Biomed Res Int 2015:1-12. https://doi.org/10.1155/2015/414681

Alloway BJ (2012) Heavy metals in soils: trace metals and metalloids in soils and their bioavailability. In: Alloway BJ, Trevors JT (eds) Third Edit. Springer, p 615

Arif MS, Riaz M, Shahzad SM et al (2018) Fresh and composted industrial sludge restore soil functions in surface soil of degraded agricultural land. Sci Total Environ 619-620:517-527. https://doi. org/10.1016/j.scitotenv.2017.11.143

Bondarczuk K, Markowicz A, Piotrowska-Seget Z (2016) The urgent need for risk assessment on the antibiotic resistance spread via sewage sludge land application. Environ Int 87:49-55. https://doi. org/10.1016/j.envint.2015.11.011

Bush K, Bradford PA (2016) $\beta$-Lactams and $\beta$-lactamase inhibitors: an overview. Cold Spring Harb Perspect Med 1-22https://doi.org/10. 1101/cshperspect.a025247Cite

Che Y, Xia Y, Liu L et al (2019) Mobile antibiotic resistome in wastewater treatment plants revealed by Nanopore metagenomic sequencing. Microbiome 7:1-13. https://doi.org/10.1186/s40168-019-0663-0

Chen Q, An X, Li H et al (2016) Long-term field application of sewage sludge increases the abundance of antibiotic resistance genes in soil. Environ Int 92-93:1-10. https://doi.org/10.1016/j.envint. 2016.03.026

Cheng W, Li J, Wu Y et al (2016) Behavior of antibiotics and antibiotic resistance genes in eco-agricultural system: a case study. J Hazard Mater 304:18-25. https://doi.org/10.1016/j.jhazmat.2015.10.037

Commission of European Communities (1986) Council Directive $86 / 278 /$ EEC of 12 June 1986 on the protection of the environment, and in particular of the soil, when sewage sludge is used in agriculture. Off j Eur Communities 4:6-12

Cucina M, Ricci A, Zadra C et al (2019) Benefits and risks of longterm recycling of pharmaceutical sewage sludge on agricultural soil. Sci Total Environ 695:133762. https://doi.org/10.1016/j.scito tenv.2019.133762

Cycoń M, Markowicz A, Borymski S et al (2013) Imidacloprid induces changes in the structure, genetic diversity and catabolic activity of soil microbial communities. J Environ Manage 131:55-65

da Silva Souza T, Lacerda D, Louzada Aguiar L, et al (2020) Toxic potential of sewage sludge: histopathological effects on soil and aquatic bioindicators. Ecol Indic 111. https://doi.org/10.1016/j. ecolind.2019.105980

de Melo G, Lavezzo L, de Araújo A et al (2018) Ten years of application of sewage sludge on tropical soil. A balance sheet on agricultural crops and environmental quality. Sci Total Environ 643:1493-1501. https://doi.org/10.1016/j.scitotenv.2018.06.254

Di Cesare A, Eckert EM, D'Urso S et al (2016) Co-occurrence of integrase 1, antibiotic and heavy metal resistance genes in municipal wastewater treatment plants. Water Res 94:208-214. https://doi. org/10.1016/j.watres.2016.02.049

Dudka S, Piotrowska M, Chlopecka A, Witek T (1995) Trace metal contamination of soils and crop plants by the mining and smelting industry in Upper Silesia, South Poland. J Geochemical Explor 52:237-250

Ellis S, Tyrrel S, O'Leary E et al (2018) Proportion of sewage sludge to soil influences the survival of Salmonella Dublin and Escherichia coli. Clean - Soil, Air, Water 46:1-7. https://doi.org/10.1002/clen. 201800042

European Commission (2014) End-of-waste criteria for biodegradable waste subjected to biological treatment (compost \& digestate): Technical proposals

European Commission (2010) Working document sludge and biowaste. Brussels, 21 September

Fortunato G, Vaz-moreira I, Becerra-castro C et al (2018) A rationale for the high limits of quantification of antibiotic resistance genes in soil. Environ Pollut 243:1696-1703. https://doi.org/10.1016/j. envpol.2018.09.128

Frostegård Å, Bååth E (1996) The use of phospholipid fatty acid analysis to estimate bacterial and fungal biomass in soil. Biol Fertil Soils 22:59-65. https://doi.org/10.1007/BF00384433

Garland JL, Mills AL (1991) Classification and characterization of heterotrophic microbial communities on the basis of patterns of community-level sole-carbon-source utilization. Appl Environ Microbiol 57:2351-2359 
Gillings MR (2018) DNA as a pollutant: the clinical class 1 integron. Curr Pollut Reports 4:49-55. https://doi.org/10.1007/s40726-018-0076-x

Gillings MR, Gaze WH, Pruden A et al (2015) Using the class 1 integron-integrase gene as a proxy for anthropogenic pollution. ISME J 9:1269-1279. https://doi.org/10.1038/ismej.2014.226

Green MR, Sambrook J (2012) Molecular cloning, A laboratory manual. Fourth edi, New York

Gudeta DD, Bortolaia V, Amos G et al (2016) The Soil Microbiota Harbors a Diversity of Carbapenem-Hydrolyzing $\beta$-Lactamases of Potential Clinical Relevance 60:151-161. https://doi.org/10. 1128/AAC.01424-15

Hamdi H, Hechmi S, Khelil MN et al (2019) Repetitive land application of urban sewage sludge: effect of amendment rates and soil texture on fertility and degradation parameters. CATENA 172:11-20. https://doi.org/10.1016/j.catena.2018.08.015

Hammer Ø, Harper DAT, Ryan PD (2001) Past: paleontological statistics software package for education and data analysis. Palaeontol Electron 4:1-9

Hu HW, Wang JT, Li J et al (2017) Long-term nickel contamination increases the occurrence of antibiotic resistance genes in agricultural soils. Environ Sci Technol 51:790-800. https://doi.org/ 10.1021/acs.est.6b03383

Ishii K, Fukui M, Takii S (2000) Microbial succession during a composting process as evaluated by denaturing gradient gel electrophoresis analysis. J Appl Microbiol 89:768-777. https://doi.org/ 10.1046/j.1365-2672.2000.01177.x

Jamieson RC, Gordon RJ, Sharples KE et al (2002) Movement and persistence of fecal bacteria in agricultural soils and subsurface drainage water: a review. Can Biosyst Eng / Le Genie Des Biosyst Au Canada 44:1-9

Jang HM, Lee J, Kim YB et al (2018) Fate of antibiotic resistance genes and metal resistance genes during thermophilic aerobic digestion of sewage sludge. Bioresour Technol 249:635-643. https://doi.org/10.1016/j.biortech.2017.10.073

Kandeler E (1995) Potential nitrification. In: Schinner F, Öhlinger R, Kandeler E, Margesin R (eds) Methods in Soil Biology. Springer, New York, pp 146-148

Karelová E, Harichová J, Stojnev T et al (2011) The isolation of heavy-metal resistant culturable bacteria and resistance determinants from a heavy-metal-contaminated site. Biologia (bratisl) 66:18-26. https://doi.org/10.2478/s11756-010-0145-0

Kim KR, Owens G, Kwon SI et al (2011) Occurrence and environmental fate of veterinary antibiotics in the terrestrial environment. Water Air Soil Pollut 214:163-174. https://doi.org/10.1007/ s11270-010-0412-2

Kirchmann H, Börjesson G, Kätterer T, Cohen Y (2017) From agricultural use of sewage sludge to nutrient extraction: a soil science outlook. Ambio 46:143-154. https://doi.org/10.1007/s13280-016-0816-3

Li AD, Li LG, Zhang T (2015) Exploring antibiotic resistance genes and metal resistance genes in plasmid metagenomes from wastewater treatment plants. Front Microbiol 6:1-11. https://doi.org/ 10.3389/fmicb.2015.01025

Makowska N, Koczura R, Mokracka J (2016) Class 1 integrase, sulfonamide and tetracycline resistance genes in wastewater treatment plant and surface water. Chemosphere 144:1665-1673. https://doi.org/10.1016/j.chemosphere.2015.10.044

Margesin R, Schinner F (2005) Manual of soil analysis-monitoring and assessing soil bioremediation. Springer-Verlag, Berlin Heidelberg

Markowicz A, Bondarczuk K, Cycoń M, Sułowicz S (2021) Land application of sewage sludge: response of soil microbial communities and potential spread of antibiotic resistance. Environ Pollut 271:116317. https://doi.org/10.1016/j.envpol.2020.116317

Mininni G, Blanch AR, Lucena F, Berselli S (2015) EU policy on sewage sludge utilization and perspectives on new approaches of sludge management. Env Sci Pollut Res 22:7361-7374. https:// doi.org/10.1007/s11356-014-3132-0
Monier JM, Demanèche S, Delmont TO et al (2011) Metagenomic exploration of antibiotic resistance in soil. Curr Opin Microbiol 14:229-235. https://doi.org/10.1016/j.mib.2011.04.010

Östman M, Lindberg RH, Fick J et al (2017) Screening of biocides, metals and antibiotics in Swedish sewage sludge and wastewater. Water Res 115:318-328. https://doi.org/10.1016/j.watres.2017. 03.011

Pagaling E, Gatica J, Yang K et al (2016) Phylogenetic diversity of ceftriaxone resistance and the presence of extended-spectrum $\beta$-lactamase genes in the culturable soil resistome. J Glob Antimicrob Resist 6:128-135. https://doi.org/10.1016/j.jgar.2016.05.002

Pal C, Bengtsson-Palme J, Kristiansson E, Larsson DGJ (2015) Cooccurrence of resistance genes to antibiotics, biocides and metals reveals novel insights into their co-selection potential. BMC Genomics 16:1-14. https://doi.org/10.1186/s12864-015-2153-5

Partridge SR, Hall RM (2005) Evolution of transposons containing bla $_{\text {TEM }}$ genes. Antimicrob Agents Chemother 49:1267-1268. https://doi.org/10.1128/AAC.49.3.1267-1268.2005

Partridge SR, Kwong SM, Firth N, Jensen SO (2018) Mobile genetic elements associated with antimicrobial resistance. Clin Microbiol Rev 31:1-61. https://doi.org/10.1128/CMR.00088-17

Pennanen T, Frostegård Å, Fritze H, Bååth E (1996) Phospholipid fatty acid composition and heavy metal tolerance of soil microbial communities along two heavy metal-polluted gradients in coniferous forests. Appl Environ Microbiol 62:420-428. https://doi.org/10. 1128/AEM.62.2.420-428.1996

Pfeifer Y, Cullik A, Witte W (2010) Resistance to cephalosporins and carbapenems in gram-negative bacterial pathogens. Int J Med Microbiol 300:371-379. https://doi.org/10.1016/j.ijmm.2010.04.005

Polish Journal of Laws (2015) Regulation of the Minister of the Environment of 6 February 2015 on municipal sewage sludge. Regul. Minist. Environ. 6 Febr. 2015 Munic. Sew. sludge item 257

Poole K (2005) Outer membranes and efflux: the path to multidrug resistance in gram-negative bacteria. Curr Pharm Biotechnol 3:77-98. https://doi.org/10.2174/1389201023378454

Protano G, Baroni F, Di Lella LA et al (2020) How do properties and heavy metal levels change in soils fertilized with regulated doses of urban sewage sludge in the framework of a real agronomic treatment program? J Soils Sediments 20:1383-1394. https://doi. org/10.1007/s11368-019-02511-3

Roig N, Sierra J, Martí E et al (2012) Long-term amendment of Spanish soils with sewage sludge: effects on soil functioning. Agric Ecosyst Environ 158:41-48. https://doi.org/10.1016/j.agee.2012.05.016

Seleiman MF, Santanen A, Jaakkola S et al (2013) Biomass yield and quality of bioenergy crops grown with synthetic and organic fertilizers. Biomass 59:477-485

Szczepanowski R, Linke B, Krahn I et al (2009) Detection of 140 clinically relevant antibiotic-resistance genes in the plasmid metagenome of wastewater treatment plant bacteria showing reduced susceptibility to selected antibiotics. Microbiology 155:2306-2319. https://doi.org/10.1099/mic.0.028233-0

Tabatabai MA, Bremner JM (1972) Assay of urease activity in soils. Soil Biol Biochem 4:479-487. https://doi.org/10.1016/0038-0717(72)90064-8

Tabatabai MA, Bremner JM (1969) Use of p-nitrophenyl phosphate soil phosphatase activity. Soil Biol Biochem 1:301-307

Tóth G, Hermann T, Da Silva MR, Montanarella L (2016) Heavy metals in agricultural soils of the European Union with implications for food safety. Environ Int 88:299-309. https://doi.org/10.1016/j. envint.2015.12.017

Urra J, Alkorta I, Mijangos I et al (2019) Application of sewage sludge to agricultural soil increases the abundance of antibiotic resistance genes without altering the composition of prokaryotic communities. Sci Total Environ 647:1410-1420. https://doi.org/10.1016/j. scitotenv.2018.08.092

Wolters B, Fornefeld E, Jechalke S et al (2019) Soil amendment with sewage sludge affects soil prokaryotic community composition, 
mobilome and resistome. FEMS Microbiol Ecol 95:1-14. https:// doi.org/10.1093/femsec/fiy193

Xia J, Psychogios N, Young N, Wishart DS (2009) MetaboAnalyst: a web server for metabolomic data analysis and interpretation. Nucleic Acids Res 37:652-660. https://doi.org/10.1093/nar/gkp356

Zelles L (1999) Fatty acid patterns of phospholipids and lipopolysaccharides in the characterisation of microbial communities in soil: a review. Biol Fertil Soils 29:111-129. https://doi.org/10.1007/s003740050533
Zhang J, Sui Q, Tong J et al (2018) Soil types influence the fate of antibiotic-resistant bacteria and antibiotic resistance genes following the land application of sludge composts. Environ Int 118:34-43. https://doi.org/10.1016/j.envint.2018.05.029

Publisher's Note Springer Nature remains neutral with regard to jurisdictional claims in published maps and institutional affiliations. 